\title{
Synthesis and Evaluation of TAC-Based Inhibitors of Papain as Mimics of Cystatin B
}

\author{
Dirk-Jan van Zoelen, ${ }^{[a]}$ Maarten R. Egmond, ${ }^{[b]}$ Roland J. Pieters, ${ }^{[a]}$ and \\ Rob M. J. Liskamp*[a]
}

An approach for mimicking protein-protein interactions by using a discontinuous epitope to construct a mimic that is about one tenth of the size of a natural inhibitor of papain, namely, cystatin $B$, is described. The discontinuous epitope of cystatin $B$, which is involved in the interaction with papain, was mimicked by synthesis of a tripodal molecular construct by using the triazacyclophane (TAC) scaffold. The mimic contains three peptide arms: one that mimics the $N$ terminus, one that mimics the $C$ terminus, and one that mimics the $\beta$-hairpin loop structure of cystatin $B$.
These peptide sequences were assembled on the TAC scaffold The resulting cystatin mimic, CysTACtin 9, showed excellent inhibition of papain with $a \mathrm{~K}_{i}$ of $12 \mathrm{nM}$, which approaches the inhibitory potency of cystatin $B\left(\mathrm{~K}_{i}=0.12 \mathrm{~nm}\right)$. Experiments with molecular constructs that contained one or two arms or a mixture of the nonscaffolded peptides showed that both scaffolding and the presence of the three peptide arms are crucial for a successful mimic.

\section{Introduction}

Protein-protein interactions play an indisputable central role in all cellular processes from the start (e.g., transcription) and maintenance of life (e.g., signal transduction, ${ }^{[1]}$ immunogenic responses ${ }^{[2]}$ ) to the ending of life (e.g., apoptosis). These processes are consequences of intricate interplays between many proteins. Multiple protein-protein interactions are usually involved, which ultimately lead to the successful completion of a particular cellular process and the ensuing biological effect. Defects in the regulation of protein-protein interactions are believed to be involved in several diseases, for example, cancer, ${ }^{[3]}$ Huntington's, ${ }^{[4]}$ autoimmune diseases, ${ }^{[5,6]}$ and osteoporosis. ${ }^{[7]}$ Therefore, many attempts have been undertaken to develop methods to modulate and possibly interfere with protein-protein interaction. ${ }^{[8]}$ Small molecules are preferred in therapeutic approaches, and considerable success has been achieved in identifying these for disruption of protein-protein interactions. ${ }^{[2]}$ However, the large surface areas that are often involved in protein-protein interactions, and which vary between $600-2000 \AA^{2}$, could be responsible for the frequently observed inability of small molecules to disrupt these interactions. Another related factor might be the divergent presentation of functional groups on the surface of proteins. ${ }^{[2]}$ Thus, compounds capable of disrupting these protein-protein interactions would have to be relatively large and complex. Therefore, interesting approaches to achieve interruption of protein-protein interactions, which include the mimicry of the bioactive interacting conformation by assembly of separate binding sites on scaffolds, need to be explored. ${ }^{[9-12]}$

In this paper we describe the use of the triazacyclophane (TAC) scaffold (Scheme 1) for proper positioning of three discontinuous epitopes of cystatin B, which are involved in inhibiting the enzymatic activity of papain, to arrive at a considera- bly smaller mimic of cystatin B. We have selected the cystatin B-papain protein complex as a proof-of-principle target and as a representative example of the regulation of a protease by a protein. The clan CA of cysteine proteases, of which papain is a representative, is involved in diseases like cancer. ${ }^{[7]}$ Moreover, by determining the enzymatic activity of papain, the effectiveness of the mimics can be conveniently evaluated.

\section{Results}

\section{Design and synthesis of cystatin mimics}

The TAC scaffold (1, Scheme 1) consists of three semiorthogonally protected secondary amines, which can be used to introduce three different peptide chains. ${ }^{[13-15]}$ The TAC scaffold was designed in such a way that solid-phase chemistry was possible by attachment of the carboxylic acid moiety to a suitable resin. ${ }^{[13-15]}$ In the synthesis approach, the Fmoc-protecting group was cleaved with piperidine (20\%) in $N$-methyl pyrrolidone (NMP) to liberate a secondary amine, which was decorated with a peptide chain. Next, the o-nitrobenzenesulfonyl

[a] D.-J. van Zoelen, Dr. R. J. Pieters, Prof. Dr. R. M. J. Liskamp Department of Medicinal Chemistry and Chemical Biology Utrecht Institute for Pharmaceutical Sciences

Utrecht University, P.O. Box 80082

3508 TB Utrecht (The Netherlands)

Fax: $(+31) 30-2536655$

E-mail:r.m.j.liskamp@uu.nl

[b] Prof. Dr. M. R. Egmond

Department of Membrane Enzymology, Utrecht University P. O. Box 80082, 3508 TB Utrecht (The Netherlands)

Supporting information for this article is available on the WWW under http://www.chembiochem.org or from the author. 


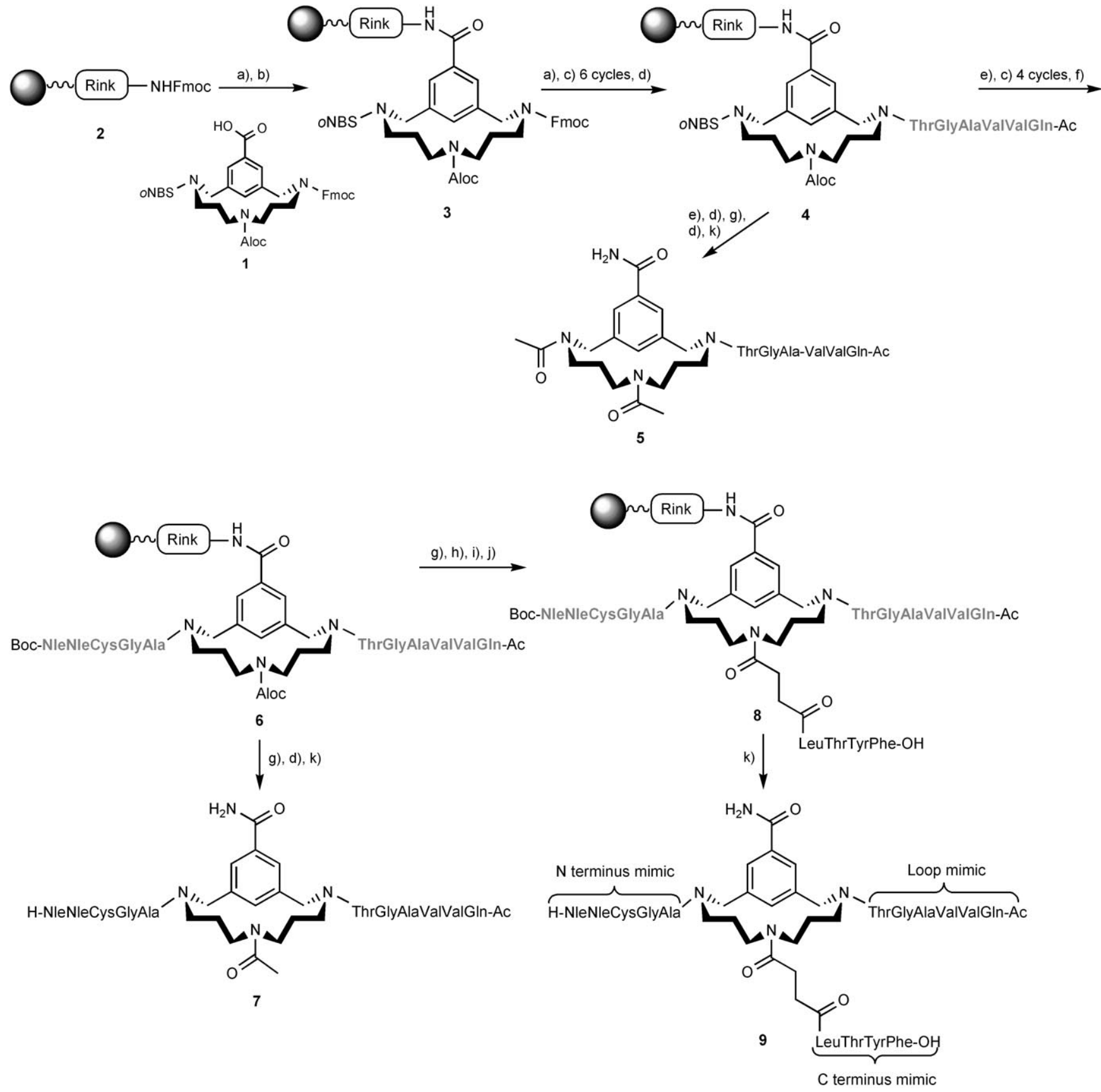

Scheme 1. Synthesis of CysTACtins 5, 7, and 9. Reagents and conditions: a) 20\% piperidine, NMP; b) TAC scaffold (1), BOP, DIPEA, NMP; c) i. Fmoc-AA-OH, BOP, DIPEA; ii. $20 \%$ piperidine, NMP; d) $\mathrm{Ac}_{2} \mathrm{O}$, DIPEA, $\mathrm{HOBt}$; e) $\mathrm{HSCH}_{2} \mathrm{CH}_{2} \mathrm{OH}, \mathrm{DBU}, \mathrm{DMF}$; f) Boc-Nle-OH, BOP, DIPEA; g) Pd(PPh $)_{4}$, anilinium $p$-toluenesulfinic acid, NMP; h) succinic anhydride, DMAP, DCM; i) BOP, NMP, $\mathrm{N}_{2}$; j) peptide 11, NMP; k) TFA/TIS/ $\mathrm{H}_{2} \mathrm{O} /$ EDT (94.5:1:2.5:2.5). The peptide sequences in gray bold letters $(\mathbf{4}, \mathbf{6}$, and $\mathbf{8})$ indicate that the side-chain protecting groups were present.

(oNBS) group was cleaved with mercaptoethanol and 1,8diazabicyclo[5.4.0] undec-7-ene (DBU), and a second peptide chain was introduced. Lastly, the Aloc group was cleaved by using $\mathrm{Pd}^{0}$, and the third peptide chain was introduced.

The target system for mimicry was cystatin $B$ as part of the papain-cystatin B complex (Figure 1). The crystal structure of this complex was elucidated in 1990 by Stubbs et al. (RCSB PDB ID: 1stf). ${ }^{[16]}$ As is shown in Figure 1, the complex consists of the protease papain (green) and its natural inhibitor cystatin B (purple). Papain is a cysteine protease isolated from papaya latex. Papain is the most widely studied member of the cysteine proteinase class of enzymes. It has a preference for substrates that contain a bulky, nonpolar side chain (e.g., Phe) on the P2 position, and some preference for Arg and Lys at the $\mathrm{P} 1$ position. ${ }^{[17]}$ Other proteases of this class are believed to be involved in cancer growth. ${ }^{[7]}$

The natural inhibitor of papain is cystatin $B$, which is a single-chain, acidic protein $(21 \mathrm{kD})$ with no disulfide bonds or carbohydrate residues. ${ }^{[18]}$ Cystatin $\mathrm{B}$ binds to papain in the subnanomolar range ${ }^{[19]}(0.12 \mathrm{~nm})$, and interacts with the enzyme 


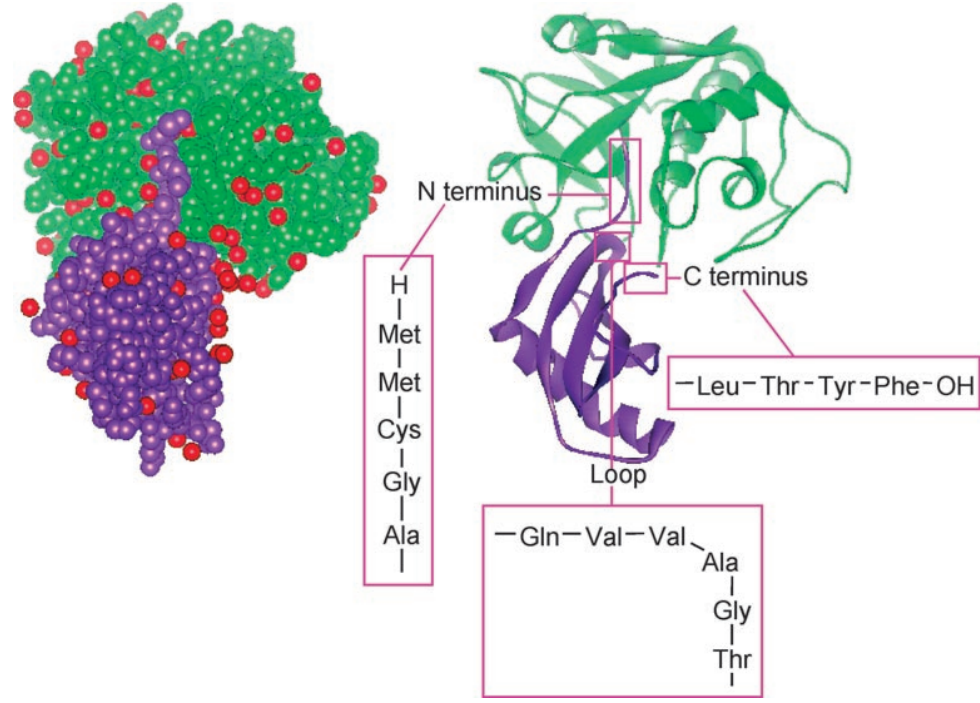

Figure 1. The crystal structure of the papain-cystatin B complex (PDB ID: 1stf). The binding peptide segments are shown in pink boxes, papain is in green, and cystatin $B$ in purple.

through three peptide segments close to the entrance to the active site. These segments are a $\mathrm{N}$-terminal sequence $\left({ }^{6}\right.$ MetMetCysGlyAla $\left.{ }^{10}\right)$, a $\beta$-hairpin loop sequence $\left({ }^{53} \mathrm{GlnValVal}\right.$ AlaGlyThr ${ }^{58}$ ) within the cystatin B backbone, and a C-terminal sequence $\left({ }^{122}\right.$ LeuThrTyrPhe ${ }^{125}$; Figure 1$)$. These three peptide segments compose a discontinuous epitope, which forms a wedge capable of blocking the entrance to the active site of papain. In this ensemble, the $\mathrm{N}$-terminal sequence is located close to the catalytic triad. ${ }^{[16]}$ By assembling this discontinuous epitope from cystatin B on the TAC scaffold we aimed to generate new tripodal inhibitors of papain-denoted as CysTACtins-that are capable of inhibiting papain by blocking access to its active site.

The peptide sequence that mimicked the $\beta$-hairpin loop

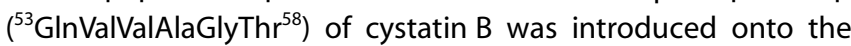
TAC scaffold after removal of the Fmoc group. Next, the se-
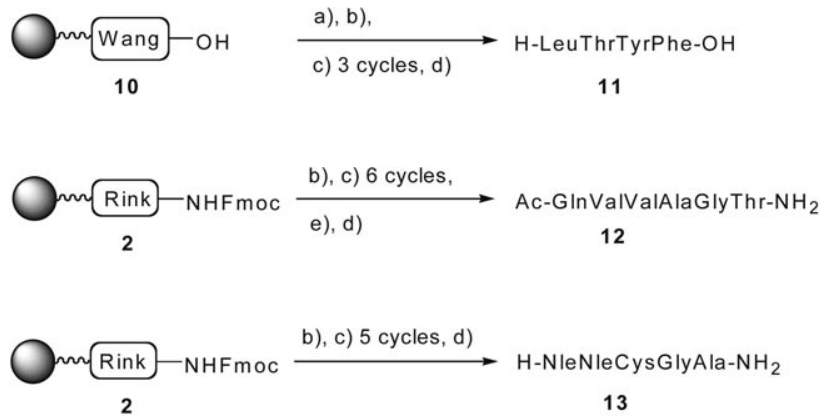

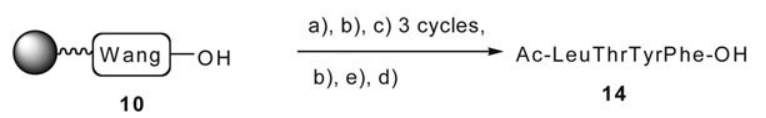

Scheme 2. Synthesis of peptide 11 and reference peptides 12-14. a) FmocPhe-OH, DCB, pyridine; b) $20 \%$ piperidine, NMP; c) i. Fmoc-AA-OH, BOP, DIPEA; ii. $20 \%$ piperidine, NMP; d) TFA, TIS, $\mathrm{H}_{2} \mathrm{O}$; e) $\mathrm{Ac}_{2} \mathrm{O}$, DiPEA, HOBt. quence that mimicked the $\mathrm{N}$-terminal peptide $\left({ }^{6} \mathrm{NleNleCys} \mathrm{GlyAla}^{10}\right)$ was introduced after removal of the oNBS protecting group. Finally, the sequence that mimicked the $\mathrm{C}$-terminal peptide $\left({ }^{122}\right.$ LeuThrTyrPhe $\left.{ }^{125}\right)$ in cystatin B was assembled on the nitrogen atom of the TAC scaffold, which was protected with an Aloc group. To circumvent oxidation, methionine residues in the $\mathrm{N}$-terminal peptide sequence were replaced by norleucine (Nle), which is common practice in organic peptide chemistry. ${ }^{[20-23]}$

The complete synthesis of CysTACtin 9 was initiated with the removal of the Fmoc group of the Rink amide argogel resin (2), and treatment with the TAC scaffold $(\mathbf{1})^{[1]}$ by using BOP as a coupling reagent (Scheme 1). Solid phase peptide synthesis (SPPS) then afforded the sequence that mimicked the $\beta$ hairpin loop of cystatin, which was subsequently acetylated to give 4 .

The peptide sequence that mimicked the $\mathrm{N}$-terminal segment of cystatin B was assembled after removal of the oNBS group in 4. The last amino acid of this sequence, that is, norleucine was introduced as a Bocprotected amino acid, which after final deprotection produced a free amino group, and indeed mimicked the amino terminus of cystatin. After succinylation of the TAC scaffold, the peptide sequence that mimicked the $C$-terminal segment of cystatin $B$ was introduced by means of reverse coupling of tetrapeptide 11 (H-LeuThrTyrPhe-OH; Scheme 2), which led to 8. The required tetrapeptide $\mathbf{1 1}$ was synthesized separately on a Wang resin (10; Scheme 2). ${ }^{[2]}$ After deprotection and cleavage from the resin, which was followed by purification, the completed desired mimic of cystatin B, that is, CysTACtin 9 was obtained in $24 \%$ yield; this corresponds to an average yield of $95 \%$ per step.

To evaluate the necessity of all three peptides on the TAC scaffold for biological activity, CysTACtins $\mathbf{5}$ and $\mathbf{7}$ were prepared analogously to CysTACtin 9 (Scheme 1). In addition, the nonscaffolded peptides $\mathrm{H}^{-}{ }^{6} \mathrm{NleNleCysGlyAla}{ }^{10}-\mathrm{NH}_{2}$ (13), Ac${ }^{53} \mathrm{GInValValAlaGlyThr}{ }^{58}-\mathrm{NH}_{2}$ (12), and $\mathrm{Ac}^{122}$ LeuThrTyrPhe ${ }^{125}-\mathrm{OH}$ (14) were synthesized by means of standard Fmoc/tBu SPPS in order to evaluate the benefits of the TAC scaffold for preorganizing the peptide segments, as opposed to merely mixing the individual peptide components (Scheme 2).

\section{Evaluation of the cystatin mimics for inhibitory activity}

The inhibitory activities of CysTACtins 5, 7, and 9, and thereby their ability to mimic the action of cystatin $B$ on papain was investigated by determining the inhibition of the conversion of peptide substrate Z-Phe-Arg-AMC. A reduction in the liberation of 7-amino-4-methylcoumarin (AMC) can be conveniently monitored by fluorescence spectroscopy ${ }^{[23]}$ An equimolar mixture (concentration range of $10-30 \mu \mathrm{M}$ ) of peptides $12-14$ was included as a control to investigate the influence of the TAC scaffold. All constructs were subjected to kinetic studies, and the inhibition curves are shown in Figure 2. The resulting in- 

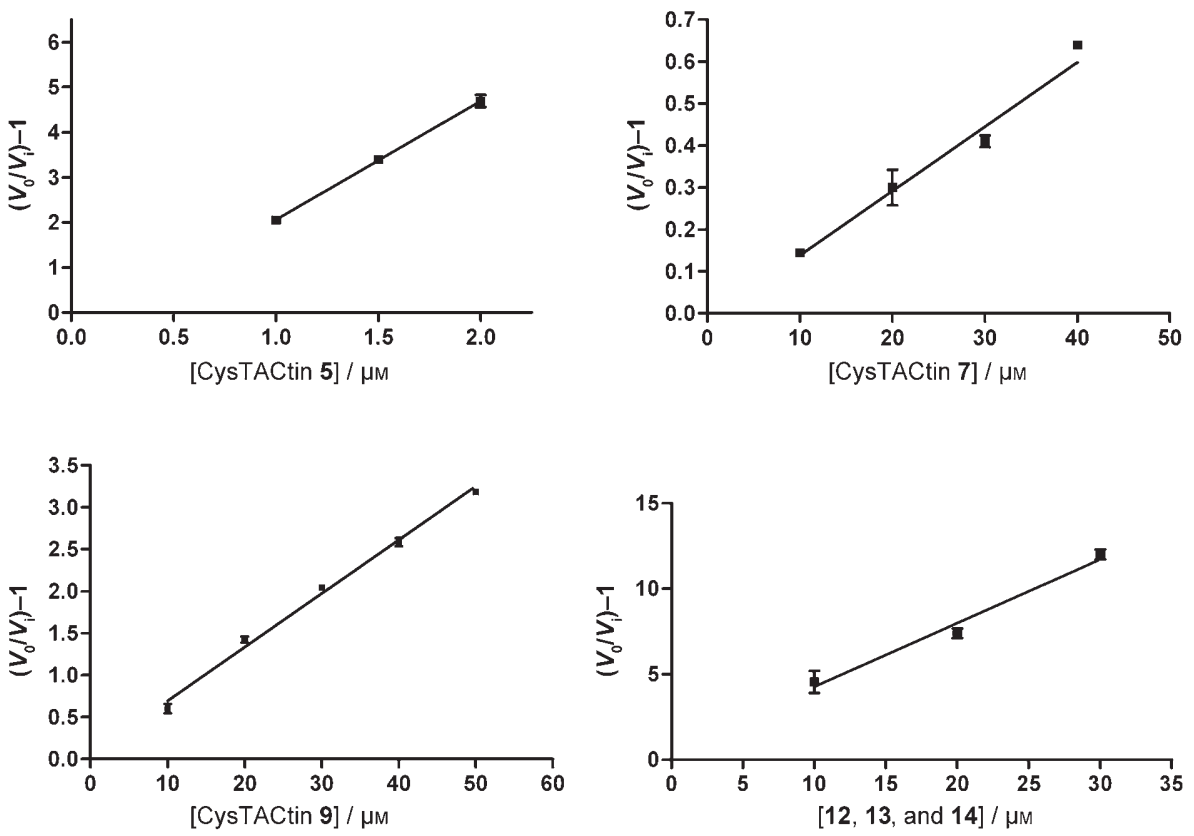

Figure 2. Inhibition curves of papain inhibited with CysTACtin 5, 7, or 9, and a control peptide mixture that consisted of 12,13 , and 14 .

hibition constants of CysTACtins 5, 7, and 9, and a 1:1:1 mixture of the nonscaffolded peptides 12-14 are summarized in Table 1.

\begin{tabular}{|c|c|}
\hline Compounds & $K_{\mathrm{i}}[\mu \mathrm{M}]$ \\
\hline CysTACtin 9 & $0.012 \pm 0.0004$ \\
\hline CysTACtin 7 & $50 \pm 4$ \\
\hline CysTACtin 5 & $290 \pm 10$ \\
\hline peptides $12-14$ & $2.0 \pm 0.2$ \\
\hline
\end{tabular}

\section{Discussion and Conclusions}

In this paper tripodal synthetic inhibitors of papain were designed and synthesized based on the crystal structure of the complex between papain and cystatin B. Three different peptide segments are involved in the binding of cystatin $B$ to papain, namely a $\beta$-hairpin loop, a $\mathrm{N}$-terminal peptide segment, and a C-terminal peptide segment. The sequences that comprise these peptide segments were assembled on the TAC scaffold by a convenient synthetic procedure, which resulted in CysTACtin 9. In addition, CysTACtins 5 and 7 were synthesized together with peptides 12-14, which correspond to the peptide segments of cystatin $B$ that are involved in the interaction with papain.

The CysTACtins 5, 7, and 9 were tested for their inhibitory activity (Table 1). CysTACtin $\mathbf{5}$, which has just one peptide arm that corresponds to the sequence of the loop, showed a modest $K_{\mathrm{i}}$ of $290 \mu \mathrm{m}$. CysTACtin 7, which has two peptide arms that correspond to the sequences of the loop and the $\mathrm{N}$ termi- nus, had an improved $K_{\mathrm{i}}$ of $50 \mu \mathrm{m}$. However, in order to reach a nanomolar range of inhibition that is comparable to that of cystatin B, all three peptide segments were needed, and CysTACtin 9 showed excellent inhibition ( $K_{\mathrm{i}} 12 \mathrm{~nm}$ ) of ZPheArg-AMC hydrolysis.

From the high $K_{\mathrm{i}}$ values of peptides 12-14, which correspond to the sequences of the separate cystatin B segments, it was concluded that the TAC scaffold was clearly necessary for proper positioning of these peptide arms. Thus, orthogonally protected TAC is a versatile scaffold for attachment of three (different) peptide arms that compose a discontinuous epitope of cystatin B involved in protein-protein interactions to give a conformation that should be similar to that observed in the cystatin B-papain protein complex.

Although these results suggest that the sequences of all three peptide segments of cystatin $B$ are required to yield an effective inhibitor, for a definitive conclusion two additional CysTACtin constructs, each of which contain two peptide arms, will have to be prepared and evaluated. Nonetheless, structural information from the X-ray structure of papain in complex with cystatin B was used successfully for the design of an effective cystatin tripodal mimic, which is much smaller than cystatin. Future studies involving, for example, NMR spectroscopy experiments and cocrystallization of CysTACtin 9 with papain will have to be performed to investigate its precise structural mimicry of cystatin B.

This strategy of designing and synthesizing effective functional mimics of discontinuous epitopes involved in proteinprotein interactions by using a small synthetic orthogonally protected (TAC) scaffold could be extended to other abundantly present examples of discontinuous epitopes in protein-protein interactions, such as, antibody-antigen interactions.

\section{Experimental Section}

General methods and materials: Synthesis of the CysTACtins was carried out manually in syringes that contained a frit. Analytical HPLC was performed by using a Shimadzu HPLC system (detection at $220 \mathrm{~nm}$ ). Preparative HPLC (detection at $220 \mathrm{~nm}$ ) was performed by using a Gilson workstation (Middleton, Wisconsin, USA). For

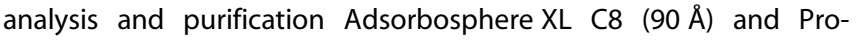
sphere $\mathrm{C} 18$ (90 $\AA$ ) columns were used, respectively, with appropriate gradients of water to water/acetonitrile buffers that contained TFA (0.1\%). ESI-MS was carried out on a Shimadzu QP-8000 LC-MS spectrometer. MALDI-TOF spectra were recorded by using a Kratos CFR spectrometer, for which $\alpha$-cyano-4-hydroxycinnamic acid 
(CHCA) was used as matrix and ACTH 18-39 as internal standard. Solid-phase resin, chemicals, and solvents were obtained commercially and used without further purification. Anilinium $p$-toluene sulfinate was prepared according to the literature procedure. ${ }^{[25]}$ Substrate Z-Phe-Arg-AMC was obtained from Bachem (Bubendorf, Switzerland). Papain (from papaya latex, E.C. 3.4.22.2; $2 \times$ crystallized, minimum activity 10 units $\mathrm{mg}^{-1}$ protein) was obtained from Sigma (Zwijndrecht, The Netherlands) and was used without further purification. Inhibition kinetics were performed by using a fluorolog fluorimeter FI 3-21 (Jobin Yvon-Horiba, Edison, NJ, USA). Graphpad prism version 4 was used to fit the inhibition curves.

Synthesis CysTACtins 5, 7, and 9, peptide 11 and peptides 12-14

General: Peptide assembly was carried out by using appropriate protected Fmoc amino acids, BOP, DIPEA, with standard amounts of equivalents (Fmoc-AA-OH/BOP/DIPEA, 4:4:8) and conditions (reaction time $1 \mathrm{~h}$, performed at room temperature in NMP). Coupling reactions were followed by using the Kaiser test ${ }^{[26]}$ (for the primary amines during amino acid couplings) and Bromophenol blue ${ }^{[27]}$ or Chloranil test ${ }^{[28]}$ (for secondary amines during coupling of amino acids to the TAC scaffold).

Peptide purification: Crude lyophilized peptide constructs were dissolved in TFA $(0.1 \%)$ in $\mathrm{H}_{2} \mathrm{O}\left(5 \mathrm{mg} \mathrm{mL}^{-1}\right)$. In the case of CysTACtin 9, mixtures of buffers $A$ and $B$ were used to dissolve the compound, and buffer $B$ was used as little as possible. Aliquots $(5 \mathrm{~mL})$ were loaded onto the HPLC column (Adsorbosphere XL C8, $90 \AA$ pore size, $10 \mu \mathrm{m}$ particle size, $2.2 \times 25 \mathrm{~cm}$ ). Peptides were eluted with a flow rate of $5 \mathrm{~mL} \mathrm{~min}^{-1}$ with a gradient from $100 \%$ buffer $A$ (0.1\% TFA in $\left.\mathrm{H}_{2} \mathrm{O} / \mathrm{CH}_{3} \mathrm{CN}, 95: 5\right)$ to $100 \%$ buffer $\mathrm{B}(0.1 \%$ TFA in $\left.\mathrm{CH}_{3} \mathrm{CN} / \mathrm{H}_{2} \mathrm{O}, 95: 5\right)$ in $50 \mathrm{~min}$, and detection was carried out at $220 \mathrm{~nm}$.

Peptide characterization: Peptide purity was analyzed with analytical HPLC by using an Adsorbosphere XL C8 or C18 column $(90 \AA$ pore size, $5 \mu \mathrm{m}$ particle size, $250 \times 4.6 \mathrm{~mm}$ ) at a flow rate of $1 \mathrm{~mL} \mathrm{~min}^{-1}$ with a gradient from $100 \%$ buffer $\mathrm{A}\left(0.1 \%\right.$ TFA in $\mathrm{H}_{2} \mathrm{O}$ / $\left.\mathrm{CH}_{3} \mathrm{CN}, 95: 5\right)$ to $100 \%$ buffer $\mathrm{B}\left(0.1 \%\right.$ TFA in $\left.\mathrm{CH}_{3} \mathrm{CN} / \mathrm{H}_{2} \mathrm{O}, 95: 5\right)$ in $40 \mathrm{~min}$, and detection was carried out at 220 and $254 \mathrm{~nm}$ by using an evaporative light scattering detector (ELSD). The peptides were further characterized either by ESI-MS or MALDI-TOF.

\section{Cleavage of Fmoc, oNBS, and Aloc protecting groups}

Fmoc cleavage: The resin was treated with a solution of piperidine $(20 \%)$ in NMP $(2 \times 6 \mathrm{~mL}$, each $8 \mathrm{~min})$. The solution was removed by filtration, and was washed with NMP $(3 \times 6 \mathrm{~mL}$, each $2 \mathrm{~min})$ and DCM $(3 \times 6 \mathrm{~mL}$, each $2 \mathrm{~min})$.

oNBS cleavage: Cleavage of the oNBS protecting group was performed by using a mixture of DBU (5 equiv) and mercaptoethanol (10 equiv) in DMF at room temperature for $30 \mathrm{~min}$; this procedure was carried out twice.

Aloc cleavage: The Aloc protecting group was cleaved by using tetrakis-(triphenylphosphine) palladium (15 mol\%) and anilinium $p$ toluenesulfinate (20 equiv) in NMP at room temperature in the dark for $2 \mathrm{~h} ;{ }^{[13]}$ this procedure was carried out twice. To remove traces of $\mathrm{Pd}^{0}$, the resin was washed three times with diethyldithiocarbamate $(0.1 \%)$ in NMP $(3 \times 5 \mathrm{~mL})$, three times with NMP $(3 \times$ $5 \mathrm{~mL})$, three times with $\mathrm{Et}_{2} \mathrm{O}(3 \times 5 \mathrm{~mL})$, and three times with NMP $(3 \times 5 \mathrm{~mL})$.

Acetylation: The remaining amines of the resin were capped twice $(2 \times 5 \mathrm{~mL})$ with capping solution, that is, $\mathrm{Ac}_{2} \mathrm{O} / \mathrm{DIPEA} / \mathrm{HOBt}(0.5 \mathrm{M} /$ $0.125 \mathrm{M} / 0.015 \mathrm{M}$ ) in NMP.
Work up after solid-phase peptide synthesis: CysTACtins and peptides were cleaved from the resin, and deprotected with TFA/ $\mathrm{TIS} / \mathrm{H}_{2} \mathrm{O}(95: 2.5: 2.5, v / v)$ or TFA/TIS/ $\mathrm{H}_{2} \mathrm{O} /$ EDT $(94: 1: 2.5: 2.5, v / v)$ at room temperature for $3 \mathrm{~h}$. Samples were precipitated with MTBE/ $n$-hexane 1:1 $(\mathrm{v} / \mathrm{v})$ at $-20^{\circ} \mathrm{C}$. Precipitates were collected by centrifugation at $3000 \mathrm{rpm}$ for $5 \mathrm{~min}$, supernatants were decanted, and the pellets were washed with MTBE $/ n$-hexane $1: 1(\mathrm{v} / \mathrm{v})$ at $-20^{\circ} \mathrm{C}$ : this procedure was carried out twice. Finally, the precipitates were dissolved in water and lyophilized.

Peptide H-LeuThrTyrPhe-OH (11): Wang resin $\left(2 \mathrm{~g} ; 0.37 \mathrm{mmol}^{-1}\right)$ was loaded with Fmoc-Phe-OH (5 equiv; $1.43 \mathrm{~g}$ ) according to the Sieber coupling protocol, ${ }^{[24]}$ loading was $0.31 \mathrm{mmolg}^{-1}$. Tetramer 11 was assembled on the resin by using standard Fmoc synthesis protocols. Amino acids used were Fmoc-Phe-OH, Fmoc- $\mathrm{Tyr}(\mathrm{tBu})-$ $\mathrm{OH}$, Fmoc-Thr(tBu)-OH, and Fmoc-Leu-OH. Peptide 11 was cleaved from the resin, deprotected, and obtained in $92 \%$ yield $(0.37 \mathrm{~g})$. ESI-MS (Figure S8): $[M+\mathrm{H}]^{+}$found $543.60,[\mathrm{M}+\mathrm{Na}]^{+}$found 565.2 , $[M]^{+}{ }_{\text {ave }}$ calcd 542.62; purity was verified by analytical HPLC (Figure S7). The identity of the peptide was further confirmed by ${ }^{1} \mathrm{H}$ NMR spectroscopy at $300 \mathrm{MHz}$. All protons were assigned by using 1D ${ }^{1} \mathrm{H} N M R$ and COSY NMR spectroscopy (Figure S9). $\delta_{\mathrm{H}}$ $\left(300 \mathrm{MHz}, \mathrm{D}_{2} \mathrm{O}\right): 0.72\left(6 \mathrm{H}, \mathrm{m}, \mathrm{CH}\left(\mathrm{CH}_{3}\right)_{2}\right.$ of Leu $), 0.84-0.86(3 \mathrm{H}, \mathrm{d}$, $\mathrm{CH}\left(\mathrm{CH}_{3}\right)$ of $\left.\mathrm{Thr}\right), 1.40\left(3 \mathrm{H}, \mathrm{m}, \mathrm{CH}_{2} \mathrm{CH}\left(\mathrm{CH}_{3}\right)_{2}\right.$ of Leu $), 2.61(1 \mathrm{H}, \mathrm{m}$, $\mathrm{CH}_{2}$-Ar of Tyr), $2.78\left(2 \mathrm{H}, \mathrm{m}, \mathrm{CH}_{2}-\mathrm{Ar}\right.$ of Tyr, $\mathrm{CH}_{2}-\mathrm{Ar}$ of Phe), $2.97(1 \mathrm{H}$, $\mathrm{m}, \mathrm{CH}_{2}$-Ar of Phe), $3.79\left(2 \mathrm{H}, \mathrm{m}, \mathrm{CHCH}_{2}\left(\mathrm{CH}_{3}\right)_{2}\right.$ of Leu, $\mathrm{CHCHCH}_{3} \mathrm{OH}$ of $\mathrm{Thr})$, 4.08-4.10 (1 H, d, $\mathrm{CHCHCH}_{3} \mathrm{OH}$ of Thr), $4.33\left(1 \mathrm{H}, \mathrm{m}, \mathrm{CHCH}_{2}-\mathrm{Ar}\right.$ of Tyr), $4.41\left(1 \mathrm{H}, \mathrm{m}, \mathrm{CHCH}_{2}-\mathrm{Ar}\right.$ of Phe $), 6.57-6.60(2 \mathrm{H}, \mathrm{d}, \mathrm{Ar}-\mathrm{H}$ of Tyr), 6.86-6.89 $(2 \mathrm{H}, \mathrm{d}, \mathrm{Ar}-\mathrm{H}$ of Tyr), $7.09(5 \mathrm{H}, \mathrm{m}, \mathrm{Ar}-\mathrm{H}$ of Phe), 8.1 $\left(2 \mathrm{H}, \mathrm{d}, \mathrm{NHCHCH}_{2}-\mathrm{Ar}\right.$ of $\mathrm{Tyr}, \mathrm{NHCHCH}_{2}-\mathrm{Ar}$ of Phe).

CysTACtin 5: Fmoc deprotected Rink amide resin $(0.2 \mathrm{~g}$; $0.29 \mathrm{mmol} \mathrm{g}^{-1}$ ) was loaded with the TAC scaffold (2 equiv; $89 \mathrm{mg}$ ), BOP (2 equiv; $51 \mathrm{mg}$ ), and DIPEA (4 equiv; $38 \mu \mathrm{L}$ ); loading was $0.2 \mathrm{mmol} \mathrm{g}^{-1}$. Remaining amines of the resin were capped. After being washed three times with NMP $(3 \times 5 \mathrm{~mL})$ the first epitope was assembled on the TAC scaffold by using standard Fmoc synthesis protocols. Amino acids used were Fmoc-Thr(tBu)-OH, FmocGly-OH, Fmoc-Ala-OH, Fmoc-Val-OH, and Fmoc-Gln(Trt)-OH. After the final Fmoc cleavage the peptide was capped twice by acetylation with capping solution $(2 \times 5 \mathrm{~mL})$. The resin was split into two equal portions. With one portion synthesis was continued by cleavage of the oNBS protecting group (DBU $22 \mu \mathrm{L}$, mercaptoethanol $20 \mu \mathrm{L})$. After the oNBS protecting group was removed the peptide construct was acetylated. To acetylate the third amino position, the Aloc-protecting group was first cleaved with tetrakis-(triphenylphosphine) palladium (6 $\mathrm{mg}$ ) and anilinium $p$-toluenesulfinate $(145 \mathrm{mg})$, and then acetylated. CysTACtin 5 was cleaved from the resin, deprotected, and obtained in $92 \%$ yield $(25.6 \mathrm{mg}, 99 \%$ per step). ESI-MS (Figure S2): $[M+\mathrm{H}]^{+}$found 959.2, $[M+\mathrm{Na}]^{+}$found 980.75, $[M]^{+}$ave calcd 958.11; purity was verified by analytical HPLC (Figure S1).

CysTACtin 7: The second portion of resin (see synthesis of CysTACtin 5) was treated with a mixture of DBU $(22 \mu \mathrm{L})$ and mercaptoethanol $(22 \mu \mathrm{L})$. The second peptide was assembled in the same manner as described above, but by using Fmoc-Ala-OH, Fmoc-Gly$\mathrm{OH}$, Fmoc-Cys(Trt)-OH, Fmoc-Nle-OH, and Boc-Nle-OH. To acetylate the third secondary amino position, the Aloc-protecting group was first cleaved with tetrakis-(triphenylphosphine) palladium $(6 \mathrm{mg})$ and anilinium $p$-toluenesulfinate $(145 \mathrm{mg})$. After acetylation, CysTACtin 7 was cleaved from the resin, deprotected, and obtained in $93 \%$ yield (37 mg, $99 \%$ per step). ESI-MS (Figure S4): $[M+2 \mathrm{H}]^{2+}$ found $688.00,[M]^{+}{ }_{\text {ave }}$ calcd 1373.66 ; the purity was verified by analytical HPLC (Figure S3). 
CysTACtin 9: Fmoc deprotected Rink resin $\left(0.9 \mathrm{~g} ; 0.29 \mathrm{mmolg}^{-1}\right)$ was loaded with the TAC-scaffold (2 equiv; $402 \mathrm{mg}$ ) by using BOP (2 equiv; $231 \mathrm{mg}$ ) and DIPEA (4 equiv; $173 \mu \mathrm{L}$ ); loading was $0.25 \mathrm{mmol} \mathrm{g}^{-1}$. The remaining amines of the resin were capped by acetylation. After being washed three times with NMP $(5 \mathrm{~mL})$, the first peptide was assembled on the TAC scaffold by using standard Fmoc synthesis protocols. Amino acids used were Fmoc-Thr(tBu)$\mathrm{OH}$, Fmoc-Gly-OH, Fmoc-Ala-OH, Fmoc-Val-OH, and Fmoc-Gln(Trt)$\mathrm{OH}$. After the final Fmoc cleavage, the peptide was acetylated with the mixture described above. About $5 \mathrm{mg}$ of resin was treated with TFA $(1 \mathrm{~mL})$ to verify the synthesis. ESI-MS: $[M+\mathrm{H}]^{+}$found 1143.45, calcd 1143.51, $[M+\mathrm{Na}]^{+}$found 1165.6 , calcd 1165.51, $[M+K]^{+}$found 1182.7 , calcd 1182.51 ; this confirmed the presence of the first peptide arm. Next, the oNBS protecting group was cleaved by using a mixture of DBU $(329 \mu \mathrm{L})$ and mercaptoethanol $(154 \mu \mathrm{L})$. The second peptide was assembled in the same manner as described above by using Fmoc-Ala-OH, Fmoc-Gly-OH, Fmoc$\mathrm{Cys}(\mathrm{Trt})-\mathrm{OH}$, Fmoc-Nle-OH, and Boc-Nle-OH as amino acids. Again, about $5 \mathrm{mg}$ of resin was treated with TFA $(1 \mathrm{~mL})$. ESI-MS: $[M+\mathrm{H}]^{+}$ found 1415.75, calcd 1415.76; this confirmed the presence of the second peptide arm. To assemble the third peptide, the Aloc-protecting group was first cleaved with tetrakis(triphenylphosphine) palladium $(41 \mathrm{mg})$ and anilinium $p$-toluenesulfinate $(1.1 \mathrm{~g})$. Next succinic anhydride (15 equiv, $0.33 \mathrm{~g}$ ) and a catalytic amount of DMAP were added to the resin and incubated for $8 \mathrm{~h}$ in dry DCM at room temperature. The resulting carboxylic acid was converted to the active OBt-ester with BOP (4 equiv, $0.39 \mathrm{~g}$ ) and DIPEA (8 equiv, $312 \mu \mathrm{L}$ ). The reaction mixture was filtered and washed three times with DCM $(3 \times 5 \mathrm{~mL})$ under a $\mathrm{N}_{2}$ atmosphere. Peptide 11 ( 2 equiv, $0.27 \mathrm{~g}$ ) was added to the resin, and the reaction mixture was shaken, overnight. After this, CysTACtin 9 was obtained after cleavage and deprotection. The crude construct was purified by preparative HPLC. Fractions were analyzed by analytical HPLC, and fractions that contained material with the correct mass were pooled and lyophilized to yield CysTACtin 9 (122 mg, 24\%; 95\% per step). ESI-MS (Figure S6): $[\mathrm{M}+2 \mathrm{H}]^{2+}$ found $978.75,[M+2 \mathrm{Na}]^{2+}$ found $991.80,[M]^{+}{ }_{\text {ave }}$ calcd 1956.32 ; purity was verified by analytical HPLC (Figure S5).

Ac-GInValValAlaGlyThr- $\mathrm{NH}_{2}$ (12): Ac-GlnValValAlaGlyThr- $\mathrm{NH}_{2}$ was synthesized by loading Fmoc- $\mathrm{Thr}(\mathrm{tBu})-\mathrm{OH}$ (4 equiv, $0.26 \mathrm{~g}$ ) on Rink amide resin $\left(0.47 \mathrm{~g}, 0.34 \mathrm{mmol} \mathrm{g}^{-1}\right.$ ) by using BOP (4 equiv, $0.26 \mathrm{~g}$ ) and DIPEA (8 equiv, $0.23 \mathrm{~mL}$ ). Peptide 12 (93 mg, 93\%) was obtained by using standard Fmoc synthesis and cleavage protocols, as described above. ESI-MS (Figure S11): $[\mathrm{M}+\mathrm{H}]^{+}$found 616.23 , calcd 615.34, $[\mathrm{M}+\mathrm{Na}]^{+}$found 638.54 , calcd 638.34 ; purity was verified by analytical HPLC (Figure S10).

H-NleNleCysGlyAla- $\mathrm{NH}_{2}$ (13): H-NleNleCysGlyAla- $\mathrm{NH}_{2}$ was synthesized by loading Fmoc-Ala-OH (4 equiv, $0.26 \mathrm{~g}$ ) on Rink amide resin $\left(0.62 \mathrm{~g}, 0.34 \mathrm{mmol} \mathrm{g}^{-1}\right)$ by using BOP (4 equiv, $0.37 \mathrm{~g}$ ) and DIPEA (8 equiv, $0.29 \mathrm{~mL}$ ). Peptide 13 (83 mg, 83\%) was obtained by using standard Fmoc synthesis and cleavage protocols, as described above. ESI-MS: could not be determined apparently due to bad ionization of the compound. The purity was verified by analytical HPLC (Figure S12).

Ac-LeuThrTyrPhe-OH (14): Ac-LeuThrTyrPhe-OH was synthesized by loading Fmoc-Phe-OH ( 5 equiv, $0.35 \mathrm{~g}$ ) on tentagel Wang resin $\left(0.59 \mathrm{~g}, 0.31 \mathrm{mmol} \mathrm{g}^{-1}\right)$ by using pyridine $(8.25$ equiv, $0.121 \mathrm{~mL})$ and 2,6-dichlorobenzoyl chloride (DCBC; 5 equiv, $0.131 \mathrm{~mL}$ ). Peptide 14 (91 mg, $91 \%$ ) was obtained by using standard Fmoc synthesis and cleavage protocols, as described above, except that before final cleavage from the resin the peptide was acetylated. ESI-MS (Fig- ure S14): $[\mathrm{M}+\mathrm{H}]^{+}$found 585.85, $[\mathrm{M}]^{+}$ave calcd 584.28. The purity was verified by analytical HPLC (Figure S13).

Inhibition assay: Inhibition kinetics of the constructs on papain was studied under pseudofirst-order conditions with at least a tenfold excess of inhibitor to enzyme. Activity was detected by the liberation of 7-amino-4-methylcoumarin (AMC) (excitation wavelength $355 \mathrm{~nm}$, emission wavelength $460 \mathrm{~nm}$ ). Initial experiments showed that a stock solution of papain was not stable because no activity was left after $2 \mathrm{~h}$, and thus papain solutions had to be prepared just before use. In the absence of substrate, autoproteolysis occurred rapidly. CysTACtins 5, 7, and 9 were preincubated at various concentrations (CysTACtin 5 (1-2 mM), CysTACtin 7 (10$40 \mu \mathrm{m})$, CysTACtin 9 (10-50 nм), and peptides 12-14 (10-30 $\mu \mathrm{m})$ ) with papain for 15 min before the reaction was started by the addition of the substrate. CysTACtins 5, 7, and 9 were dissolved in assay buffer. Assay conditions were as follows: sodium phosphate buffer $(0.1 \mathrm{~N}, \mathrm{pH} 6.5)$ containing DTT (2 mM) and EDTA (1.5 mM). Papain concentration was $0.2 \mathrm{nM}$ and Z-Phe-Arg-AMC was $10 \mu \mathrm{M}$. Three cuvettes with different concentrations of inhibitor and one cuvette without inhibitor were monitored simultaneously. The cuvette without inhibitor provided the initial rate of hydrolysis $\left(V_{0}\right)$. The three other cuvettes provide the $V_{\mathrm{i}}$ (rate of hydrolysis in the presence of inhibitor $(\mathrm{I}))$, and $\left(V_{0} / V_{i}\right)-1$ was plotted as a function of inhibitor concentration. The $K_{\mathrm{i} \text {,app }}$ was calculated by using $K_{\mathrm{i} \text {,app }}=$ $[1] /\left(\left(V_{0} / V_{i}\right)-1\right)$. By taking the substrate into consideration, the true $K_{\mathrm{i}}$ was calculated with $K_{\mathrm{i}}=K_{\mathrm{i}, \text { app }} /\left(1+\left([\mathrm{S}] / K_{\mathrm{m}}\right)\right)$. The $K_{\mathrm{m}}$ of Z-PheArg-AMC was calculated by using Michaelis-Menten kinetics, ${ }^{[18,30]}$ and found to be $32 \mu \mathrm{M}$, which is in agreement with the literature value $(65 \mu \mathrm{M})$. $^{[31]}$

\section{Acknowledgements}

We thank Hans W. Hilbers for his assistance with the modeling.

Keywords: discontinuous epitopes · inhibitors · peptides peptidomimetics

[1] F. J. Dekker, N. J. de Mol, J. van Ameijde, M. J. E. Fischer, R. Ruijtenbeek, F. A. M. Redegeld, R. M. J. Liskamp, ChemBioChem 2002, 3, 238.

[2] M. W. Peczuh, A. D. Hamilton, Chem. Rev. 2000, 100, 2479.

[3] H. zur Hausen, Nat. Rev. Cancer 2002, 2, 342.

[4] P. Harjes, E. E. Wanker, Trends Biochem. Sci. 2003, 28, 425.

[5] T. Wen, L. Zhang, S. K. P. Kung, T. J. Molina, R. G. Miller, T. W. Mak, Eur. J. Immunol. 1995, 25, 3155.

[6] T. J. Molina, K. Kishihara, D. P. Siderovski, W. Van Ewijk, A. Narendran, E. Timms, A. Wakeham, C. J. Paige, K. U. Hartmann, Nature 1992, 357, 161.

[7] F. Lecaille, J. Kaleta, D. Broemme, Chem. Rev. 2002, 102, 4459.

[8] M. W. Peczuh, A. D. Hamilton, Chem. Rev. 2000, 100, 2479; R. Jain, J. T. Ernst, O. Kutzki, H. Soon Park, A. D. Hamilton, Mol. Diversity 2004, 8, 89; H. Yin, A. D. Hamilton, Angew. Chem. 2005, 117, 4200; Angew. Chem. Int. Ed. 2005, 44, 4130.

[9] H. S. Park, Q. Lin, A. D. Hamilton, J. Am. Chem. Soc. 1999, 121, 8.

[10] R. Franke, C. Doll, V. Wray, J. Eichler, Protein Pept. Lett. 2003, 10, 531; R. Franke, C. Doll, V. Wray, J. Eichler, Org. Biomol. Chem. 2004, 2, 2847.

[11] P. Virta, M. Karskela, H. Loennberg, J. Org. Chem. 2006, 71, 1989.

[12] M. Mutter, G. Tuchscherer, Chimia 2000, 54, 552.

[13] T. Opatz, R. M. J. Liskamp, Org. Lett. 2001, 3, 3499; T. Opatz, R. M. J. Liskamp, J. Comb. Chem. 2002, 4, 275.

[14] C. Chamorro, J.-W. Hofman, R. M. J. Liskamp, Tetrahedron 2004, 60, 8691.

[15] M. C. F. Monnee, A. J. Brouwer, R. M. J. Liskamp, QSAR Comb. Sci. 2004, $23,546$.

[16] M. T. Stubbs, B. Laber, W. Bode, R. Huber, R. Jerala, B. Lenarcic, V. Turk, EMBO J. 1990, 9, 1939. 
[17] Handbook of Proteolytic Enzymes, Vol. 2 (Eds.: A. J. Barrett, N. D. Rawlings, J. F. Woessner) 2nd ed., 2004, pp. 1125.

[18] V. Turk, W. Bode, FEBS Lett. 1991, 285, 213.

[19] B. Lenarcic, I. Krizaj, P. Zunec, V. Turk, FEBS Lett. 1996, 395, 113.

[20] R. Munier, G. N. Cohen, Biochim. Biophys. Acta 1959, 31, 378.

[21] P. P. Roller, A. Otaka, M. Nomizu, M. S. Smyth, J. J. Barchi, Jr., T. R. Burke, Jr., R. D. Case, G. Wolf, S. E. Shoelson, Bioorg. Med. Chem. Lett. 1994, 4, 1879.

[22] M. Ruiz-Gayo, V. Dauge, I. Menant, D. Begue, G. Gacel, B. P. Roques, Peptides 1985, 6, 415.

[23] J. O. Lampen, M. J. Jones, Arch. Biochem. 1947, 13, 47

[24] P. Sieber, Tetrahedron Lett. 1987, 28, 6147.

[25] P. M. Selzer, S. Pingel, I. Hsieh, B. Ugele, V. J. Chan, J. C. Engel, M. Bogyo, D. G. Russell, J. A. Sakanari, J. H. McKerrow, Proc. Natl. Acad. Sci. USA 1999, 96, 11015
[26] E. Kaiser, R. L. Colescott, C. D. Bossinger, P. I. Cook, Anal. Biochem. 1970 34, 595.

[27] V. Krchnak, J. Vagner, P. Safar, M. Lebl, Collect. Czech. Chem. Commun. 1988, 53, 2542.

[28] T. Vojkovsky, Pept. Res. 1995, 8, 236.

[29] M. Honda, H. Morita, I. Nagakura, J. Org. Chem. 1997, 62, 8932.

[30] R. Eisenthal, A. Cornish-Bowden, Biochem. J. 1974, 139, 715.

[31] S. Zucker, D. J. Buttle, M. J. H. Nicklin, A. J. Barrett, Biochim. Biophys. Acta Protein Struct. Mol. Enzymol. 1985, 828, 196.

Received: May 7, 2007

Published online on September 20, 2007 